\title{
ARE SPANISH UNIVERSITY STUDENTS READY FOR LECTURES IN ENGLISH?
}

\author{
Robert Halir $^{1 *}$, Salomé Yelamos-Guerra ${ }^{2}$ \\ 1 Universidad de Málaga, ETSI Telecomunicación, Málaga (SPAIN) \\ ¿2Universidad de Málaga, Fac. Filosofía y Letras, Málaga (SPAIN) \\ *rhalir@uma.es
}

\begin{abstract}
Content Language Integrated Learning is attracting increasing attention at the University Level. However, the capabilities and expectations and of students regarding subjects in a second language are often not clear. He we present the results of a 200-student survey in three different disciplines at University of Málaga, revealing that more than $55 \%$ of students would take a mandatory subject in English. Of these, $60 \%$ prefer focus on content rather than language, more than $70 \%$ prefer a lecturer that explains clearly in correct English over a speaker that is native or holds a C1 certificate, and only $40 \%$ would like to take evaluation exams in English.
\end{abstract}

Keywords: Content Language Integrated Learning, University, Survey

\section{INTRODUCTION}

Foreign language skills, particularly in English, are becoming increasingly important for the employability of university students, and are fostered through mobility programs such as Erasmus [1]. However, Spanish students that do not opt for such a mobility experience find few opportunities to improve their language skills in the framework of their degrees, because lectures are delivered almost exclusively in Spanish. Content language integrated learning (CLIL), i.e. acquiring knowledge in a specific subject through a second language [2-4], could provide such an opportunity and is attracting considerable attention university level. However, implementing a CLIL course poses a series of challenges: i) lecturers need to ensure they are fluent in English; ii) lecturers should receive proper CLIL methodological training [5,6]; iii) lecturers need to gauge students' expectations and capabilities for such a course. While the first two aspects can be addressed by the lecturer alone, the third aspect is highly dependent on the students' attitude and previous knowledge. To gain some insight into this aspect we carried out a survey among a total of 200 students in different semesters of 3 different disciplines (electrical engineering, biology and medicine) at the University of Málaga (UMA), the results of which are reported here.

\section{METHODOLOGY}

The questionnaire we used for the survey is shown in Fig. 1. It was designed with input from colleagues from several disciplines and is divided essentially into three parts. The first five questions provide some "warm-up" for the students as well as some basic information for classification. The next six questions (numbers 6 to 11) deal with the expectations and capabilities of the students. The last questions are aimed at finding out if a student would take a mandatory or optional subject in English.

The questionnaire was implemented with a "Google Forms" survey that students can complete using any internet connected device - the form is available online [7]. In order to obtain a representative sample, we asked students to fill in the form during a lecture using their smartphones; leaving the form as "homework" would introduce selection bias, because only those students already interested in English would complete it. A different copy of the form was used for the different group of students, which enabled us to differentiate between students in different disciplines and in different semesters; otherwise the survey was completely anonymous. In total, 217 students took the survey, of which 105 study engineering, 70 Biology and 42 medicine.

While Google Forms provides basic statistics on the answers, we exported the resulting data to a Matlab environment for more advanced processing. We excluded two groups of students from the results: non-native Spanish speakers (Question 1: Spanish is my mother tongue - No), and unmotivated students (Question 5: Regarding the degree I am pursuing - I wonder what I'm doing here). The number of students in these two groups was small (out of the 217 students, 11 were 
1) Spanish is my mother tongue.
a. Yes
b. No

2) My gender is: [answer is optional]
a. Female
b. Male

3) I think a subject in English is
a. an interesting opportunity if well designed.
b. unnecessary, an academy is preferable.

4) For my first job, I think having taken a subject in English we be:
a. Useful
b. Useless

5) Regarding the degree I am pursuing:
a. I like it and I am getting good grades.
b. I like it, but I am struggling
c. I wonder: What am I doing here?

6) What should be the main goal of a subject in English?
a. Teach English, even if this means reducing content.
b. Teach Content; improving English could be side effect for some students.
c. Something in between of a. and b.

7) What should be English (you can tick several items):
a. Lecture notes / slides.
b. The lecture's explanation.
c. The classroom interaction.
d. The evaluation.

8) The minimum English level for students:

a. There should be no minimum requirement
b. They should be able to discuss a technical question.
c. They should hold a B1 certificate.
d. They should hold a B2 certificate.

9) The minimum English level for the lecturer:

a. He/she should be a native speaker.

b. He/she should hold a C1 certificate.

c. He/she should be able to explain clearly in correct English.

10) What recognition should students receive?
a. None is necessary.
b. The academic record should state the subject is in English.
c. The amount of credit points for the subject should be higher.

11) I judge my English level as:
a. Basic - present yourself, read and write short texts.
b. Intermediate - I can have a fluid conversation, read and write long texts.
c. Advanced - I am fluent on all levels, I could write my Bachelor Thesis in English.

12) Would you take a mandatory subject in English?
a. No, I am not sure I would be able to follow.
b. No, because the technical content of the subject might be reduced.
c. Yes, I like the idea and think I'd fare well.
d. Yes, but only if there is some type of recognition.
13)Would you take an optional subject in English? - Same options as 12).
14) If you have any comments please let us know here. - Free form reply.

Figure 1. The questionnaire used to gauge students' expectations and capabilities for lectures in English [7].

unmotivated and 19 were non-native), and excluding them only produces changes of about 1 percent point in the results reported below.

\section{RESULTS}

In the following we describe the statistical results of some of the most relevant questions in the survey (see Fig. 1).

Regarding the main goal of a subject in English (question 6), approximately 60\% of students considered it should be teaching solely content (option 6b), whereas about $40 \%$ favoured a CLIL-like approach (answer 6c). Regarding the lecturer's English level (question 9), 70\% of students prefer a lecturer that explains clearly in correct English over a native speaker or somebody that holds a C1 certificate. These answers suggest that, as one might expect, students' primary concern is delivery of the technical content.

Let us now focus on whether students would actually be ready to take a mandatory o optional subject in English (questions 12 and 13). The statistical results are broken down in Table 1. Considering students from all disciplines we found that $56 \%$ would take a mandatory subject in English (answers $12 \mathrm{c}$ and 12d), whereas 77\% would take an optional subject in English (answers 13c and 13d). 
Table 1. Statistical results of selected questions, excluding non-native Spanish speakers and non-motivated students

\begin{tabular}{|c|c|c|c|c|c|}
\hline Question & Restriction & $\begin{array}{c}\text { All disciplines } \\
\text { (187 students) }\end{array}$ & $\begin{array}{l}\text { Engineering } \\
\text { (91 students) }\end{array}$ & $\begin{array}{l}\text { Biology } \\
\text { (58 students) }\end{array}$ & $\begin{array}{c}\text { Medicine } \\
\text { (38 students) }\end{array}$ \\
\hline \multirow{6}{*}{$\begin{array}{l}\text { Take } \\
\text { mandatory } \\
\text { / optional } \\
\text { subject }\end{array}$} & None & $56 \% / 77 \%$ & $60 \% / 81 \%$ & $46 \% / 63 \%$ & $58 \% / 87 \%$ \\
\hline & $\begin{array}{l}\text { Basic } \\
\text { English }\end{array}$ & $30 \% / 47 \%$ & $40 \% / 47 \%$ & $20 / 47 \%$ & -- \\
\hline & $\begin{array}{c}\text { Intermediate } \\
\text { English }\end{array}$ & $55 \% / 80 \%$ & $59 \% / 84 \%$ & $53 \% / 67 \%$ & $50 \% / 88 \%$ \\
\hline & $\begin{array}{l}\text { Advanced } \\
\text { English }\end{array}$ & $81 \% / 94 \%$ & $\begin{array}{l}82 \% / \\
100 \% \\
\end{array}$ & $\begin{array}{c}100 \% / \\
100 \% \\
\end{array}$ & $75 \% / 83 \%$ \\
\hline & $\begin{array}{c}\text { Good } \\
\text { Students }\end{array}$ & $62 \% / 84 \%$ & $66 \% / 93 \%$ & $52 \% / 68 \%$ & $63 \% / 84 \%$ \\
\hline & $\begin{array}{l}\text { Average } \\
\text { Students }\end{array}$ & $48 \% / 67 \%$ & $55 \% / 70 \%$ & $42 \% / 59 \%$ & $\begin{array}{l}20 \% / \\
100 \% \\
\end{array}$ \\
\hline \multirow{4}{*}{$\begin{array}{l}\text { Evaluation } \\
\text { in English }\end{array}$} & None & $33 \%$ & $20 \%$ & $28 \%$ & $71 \%$ \\
\hline & $\begin{array}{l}\text { Basic } \\
\text { English }\end{array}$ & $7 \%$ & $13 \%$ & $0 \%$ & -- \\
\hline & $\begin{array}{c}\text { Intermediate } \\
\text { English }\end{array}$ & $35 \%$ & $15 \%$ & $38 \%$ & $77 \%$ \\
\hline & $\begin{array}{l}\text { Advanced } \\
\text { English }\end{array}$ & $47 \%$ & $42 \%$ & $33 \%$ & $58 \%$ \\
\hline
\end{tabular}

This trend continues if we consider only students from Engineering, Biology or Medicine (first row of Table 1). The fact that more students are ready to take an optional subject in English, is probably because optional subjects are generally considered "easier", and are not needed as foundations for other subjects.

The second row of the table shows the statistics that result if we consider only students which judge their English level as "basic" (answer 11a). In this case, the percentage of students ready to take subject in English drops significantly across all disciplines. We note that in Medicine, there were no students with "Basic" English. This is probably due to two facts: i) Medicine is the most selective discipline at our University, ii) only in Medicine the survey was carry out as "homework" for the students, thereby introducing a selection bias. Among students with intermediate and advanced English the fraction that would take lectures in English is of course much higher, reaching up to $100 \%$ for optional subjects. If we compare good students (those that judged their grades as good - answer $5 \mathrm{a}$ ), and average students (those that said they were struggling with some subjects - answer $5 \mathrm{~b}$ ), we find that find that the former a more likely to take a subject in English than the latter.

Regarding evaluation, we found that overall only $33 \%$ of students would be comfortable with exams in English. That fraction is even lower among Engineering students (20\%), but much larger in Medicine, probably due to the selection bias we mentioned before. As expected, students with a higher English level are more comfortable with exams in English, but even among those who consider their English Advanced, only about half $(47 \%)$ would like to be evaluated in English. Of all students that would take a mandatory subject in English, again only $40 \%$ feel comfortable with exams in English. We attribute this mainly to "fear of the unknown" that lecturers will have to address, for instance, by doing sample exams in the classroom.

\section{CONCLUSIONS}

Our survey, while by no means exhaustive, shows that there is a significant potential for teaching in English across disciplines. Students naturally emphasis content delivery and expect the lecturer to be fluent in English (but not necessarily a native speaker). Evaluation in English is a sensitive aspect that will have to be addressed with care. 


\section{ACKNOWLEDGEMENTS}

We would like to thank our colleagues at UMA their help and contributions to the survey, and acknowledge funding from the Universidad de Málaga.

\section{REFERENCES}

[1] U. Brandenburg, S. Berghoff, and O.T. Álvarez, "The Erasmus Impact Study", European Commission, Section 3.4, 2014

[2] D. Coyle, "Content and language integrated learning: Motivating learners and teachers", Scottish Languages Review 13, 2006.

[3] David Lasagabaster and Aintzane Doiz, "CLIL students' perceptions of their language learning process", Language Awareness 25, 2016

[4] U. Smit and E. Dafouz, "Integrating content and language in higher education", AILA Review 25, 2012

[5] M. Aguilar and R. Rodríguez, "Lecturer and student perceptions on CLIL at a Spanish university," International Journal of Bilingual Education and Bilingualism 15, 2012

[6] D. L. Banegas, "CLIL teacher development: Challenges and experiences," Latin American Journal of Content \& Language Integrated Learning 5, 2012.

[7] R. Halir and S. Yélamos-Guerra, Google Forms questionnaire https://goo.gl/forms/386UC5HnNDJWR5Bl1 